Indonesia Journal of Learning Education and Counseling

Website: https://journal.ilininstitute.com/index.php/IJoLEC

Vol 2, No 2, 2020, pp 204-210

p-ISSN:2622-8068 dan e-ISSN: 2622-8076

\title{
Computer Based Testing in Senior High School on National Examination
}

\author{
Alek $^{1}$, Abdul Gafur Marzuki ${ }^{2}$, Muhammad Farkhan $^{3}$, Dede Surahman ${ }^{4}$, \\ Dedi Daryanto ${ }^{5}$, Sanidaya Febrianto ${ }^{6}$ \\ ${ }^{1}$ English Education Department, UIN Syarif Hidayatullah Jakarta \\ Email: alek@uinjkt.ac.id \\ ${ }^{2}$ English Education Department, IAIN Palu \\ Email: gbudiperwira@gmail.com \\ ${ }^{3}$ English Education Department, UIN Syarif Hidayatullah Jakarta \\ Email: farkhan@uinjkt.ac.id \\ ${ }^{4}$ English Education Department, UIN Syarif Hidayatullah Jakarta \\ Email: dede.surahman16@mhs.uinjkt.ac.id \\ ${ }^{5}$ English Education Department, UIN Syarif Hidayatullah Jakarta \\ Email: dedi.daryanto16@mhs.uinjkt.ac.id \\ ${ }^{6}$ English Education Department, UIN Syarif Hidayatullah Jakarta \\ Email: sanidaya.febrianto16@mhs.uinjkt.ac.id
}

\section{Artikel info}

\section{Article history:}

Received: November-2019

Revised: December-2019

Accepted: February-2020

Publish: March-2020

\section{DOI:}

doi.org/10.31960/

ijolec.v2i2.340

\section{Keywords:}

Computer-Based Test

(CBT);

Students' Perception;

National

Examination.
Abstract. The aim of this study is to investigate the students' perception of computer-based testing in national examination and determine the extent to which cheating in exams would be eliminated by the adoption of CBT in National examination. Relevant to the purpose of the study, the researchers decide to use a qualitative case study since it was taken place in a natural setting and the data was collecting using questionnaire. This study conducted in one of senior high school in Jakarta Timur. Then, the participants in this study were 30 students of twelfth-grade students. The results of this study are almost 30 students give their perception that the $\mathrm{CBT}$ is the effective one for the students in the final examination and the CBT produces a good final examination the elimination of cheating cases in the national examination consumes time in each question.

\section{Correspondent author:}

Abdul Gafur Marzuki

IAIN Palu, Jalan Diponegoro No. 23 Kota Palu, Sulawesi

Tengah, Indonesia

Email: gbudiperwira@gmail.com

artikel dengan akses terbuka dibawah licenci CC BY-NC-4.0

\section{INTRODUCTION}

Computer-based Test (CBT) play an essential test with tool to test the students in examination with application inside the computer with limited times. Nowadays, by using computer Based Test (CBT), the student gets examination including listening, reading and writing with aim to know how far the students in using their knowledge. Nowadays, some senior high schools have prepared the examination use Computer-based Test (CBT) as a new test. It is cause of Computer Based Test (CBT) is the best way for students in examination to avoid the students from cheat, and waste their times while answering the questions in during the test. Not only has that Computer-based testing become the next tool in testing where this test is the solution for the testing problems in many countries (Hillier, 2015; Su, \& Cheng, 2015; Zygouris \& Tsolaki, 2015; All et al., 2016; Darmawan \& Harahap, 


\section{5 | Indonesia Journal of Learning Education and Counseling}

2016). As a tool of measurement, Computerbased testing is a tool that could make testing cheaper than the other testing nowadays. CBT also could produce better assessments for every student from primary level until higher learning.

Not to mention that Computer-based tests give some several benefits test. Assessment by technology gives some opportunities to measure complex form of knowledge and reasoning that is not possible to engage and assess through traditional methods (Mueller \& Piper, 2014; Yovel et al., 2014; Kraushaar \& Novak, 2019). In Indonesia, some employers now should use test for job seekers through electronic. Not only employers but also some school, universities and other institutions are almost using electronic examination for the students that including the internet and other electronic or using networking gadgets. On the other hand, there is research before that using computer and related technologies provide powerful tools to meet the new challenges of designing and implementing assessments methods that go beyond the conventional practices and facilities to record a broader repertoire of cognitive skills and knowledge (Yovel et al., 2014; Kaufman, 2018; He \& Freeman, 2019). However, the study of this research has different way in testing the students that using CBT (Computer Based Test) that using such as e-assessment, computerized testing and computer-administered testing that defined as a test or assessment that is administered or delivered on computers, either online or on a local area network.

Base on explained above, Computer Based Test (CBT) is the new way that school used in testing or giving an assessment for their students. However this study focused in investigate on how the students' perception toward testing and determine the extent to which cheating in examinations would be eliminated by the adoption of CBT in National examination by using computer Based Test (CBT) in senior high school.

During the past few years, technology has significantly reshaped the method of assessment. In many academic domains, educational measurement has been moving towards the use of computer-based testing (CBT), defined as tests or assessments that are administered by computer in either stand- alone or dedicated network, or by other technology devices linked to the internet or worldwide web most of them using multiplechoice questions (MCQs) (Sorana-Daniela \& Lorentz, 2007; Hillier, 2015; Zygouris \& Tsolaki, 2015). Computer-based tests have been used since 1960s to test knowledge and problem-solving skills (Erle et al., 2006). Computer-based assessment systems have enabled educators and trainers to author, schedule, deliver, and report on surveys, quizzes, tests, and exams. There are two main types of computer-based testing. The most familiar type is where can dates fill in their responses on a paper form, which is fed into a computer optical mark reader. This reads the form, scores the paper, and may even report on the test reliability. The second type of computer-based testing is where computers provide an assessment interface for students: they input their answers and receive feedback via computer (Erle et al., 2006; Parker et al., 2008).

An effective method of student assessment is necessary in chemistry as well as all areas and levels of education. Due to an increase in student numbers, ever-escalating work commitments for academic staff, and the advancement of internet technology, the use of computer assisted assessment has been an attractive proposition for many higher education institutions (Kraushaar \& Novak, 2019). Since their first use, computer-assisted test construction systems have made a major impact on the design and generation of chemistry examinations in many universities and colleges.

Generally, the advantages of CBT systems over traditional paper-and-pencil testing (PPT) have been demonstrated in several comparative works and as mentioned by (Erle et al., 2006; Parker et al., 2008), CBT is not just an alternative method for delivering examinations, it represents an important qualitative shift away from traditional methods such as paper based tests. Despite, these advantages available in computerized test administration as it was shown that, it does not mean that CBTs are intrinsically better than paper-and-pencil tests (Erle et al., 2006; Parker et al., 2008; Kaufman, 2018). Previous study by Meyer \& Hill, have even found hat testing format does not affect test scores and as such CBT can be considered a valid and acceptable testing mode. 
As CBT began to be used for summative assessment, establishing whether computer based testing performance was comparable to that of paper based assessment became important. Researchers have performed large scale reviews of studies examining differences in performance of CBT and paper-based version of tests and have generally found that when CBT is similar in format to pencil and paper tests, it has little if any effect on test performance (Parker et al., 2008; Kaufman, 2018). From students' perspective of the CBT there have been a number of mixed reactions. Previous research) showed that more people anticipated problems with the computer assisted assessment than actually had them (Parker et al., 2008; Kaufman, 2018). Their research also showed that despite fewer students being confident about CBT before completing the assessment more students stated a preference for CBT afterwards.

Previous study conducted indicated a preference for CBT over PPT (Parker et al., 2008; Kaufman, 2018). Some studies reported the main disadvantage as being increased anxiety among those unfamiliar with use of computer (Yovel et al., 2014; Darmawan \& Harahap, 2016) and as such students agreed that they are 'technophobic'. The challenge to test examines by means of microcomputers demands appropriate software design. To comply with this demand, students' beliefs or perceptions on the advantages and disadvantages of a computerized test are important since user perceptions and criticism are crucial in the acceptance, implementation and improvement of computerized tests.

Furthermore, whilst recognizing the system level advantages associated with CBT it is important to explore the relationship between assessment mode and the behaviour of the students being assessed. If the term 'affordaces' is used to describe what is made possible and facilitated, and what is made difficult and inhibited by a medium of assessment (Johnson \& Green, 2004). It is possible that the affordances offered by computer mediated assessment may affect the perceptions of students involved in computerbased assessment differently than if they were engaged in paper-based assessment (Parker et a1., 2008; Kaufman, 2018).

All perception involves signals in the nervous system, which in turn result from physical stimulation of the sense organs. for example, vision involves light striking the retinas of the eyes, smell is mediated by odor molecules and hearing involves pressure waves . Perception is not the passive receipt of these signals but can be shaped by learning, memory, and expectation (Mueller \& Piper, 2014; He \& Freeman, 2019).

However, the writers conclude that perception is a process which individuals receives, organize and interpret their sensory perceives which comes to people through five sense in order to give meaning to their environment. However, what one sees can be substantially different from objective reality. People knowledge of the world comes through their sense organs. Therefore, there are five tippers of perceptions that are sight or vision perception, which is directly related to the eyes and processing information from the environment. Next, hearing or auditory perception, which is the ability to perceive sound by detecting vibrations changes in the pressure of the surrounding medium through time, through an organ such as the ear.

\section{METHOD}

The purpose of this study is to investigate the students' perception of computer-based testing in national examination and determine the extent to which cheating in examinations would be eliminated by the adoption of CBT in National examination. Relevant to the purpose of the study, the researchers decide to use a qualitative case study since it was taken place in a natural setting and the data was collecting using questionnaire (Baskarada, 2014; Hyett et al., 2014; De Massis \& Kotlar, 2014; Houghton et al., 2015; Yazan, 2015; HaddockMillar et al., 2016; Harrison et al., 2017; Marzukib, 2019).

This study was conducted in one of senior high school in Jakarta Timur. Then, the Participant in this study is 30 students of twelfth-grade students.

In this study the data were obtained from questionnaire. The questionnaire is a form used in survey design that the participants in a study complete and return to the researcher (Marzuki, 2016; Marzuki, 2017). Relevant to the statement, this research employed closeended questionnaire. In this case, the questionnaire was used to investigate the students' perception about computer-based 


\section{7 | Indonesia Journal of Learning Education and Counseling}

testing in national examination and determine the extent to which cheating in examinations would be eliminated by the adoption of CBT in National examination. It was mentioned above this research employed the close-ended questionnaire in order to gain the data from the students. The data were analyzed in some steps. The first step was converting the respondents' answer to numbers by means of the coding procedure. The second step was calculating the students' answer and last step was giving the percentages of their answer (Marzuki, 2018; Marzuki, 2019a).

\section{RESULTS AND DISCUSSION}

Literally at the beginning of this research, the researchers interviewed with the 30 students who used test using ComputerBased Testing on their final exam. With the interview guide of CBT the researchers gained information about their knowledge and perception about the situation after and before using the Computer Based Test (CBT). Almost of the students in this school who used CBT on their final examination are agree with the rules of the school that uses Computer Based Test (CBT) on their final examination with some reasons. Here is the result of the students' interview guide from their experiments when they used Computer Based Test on their final examination:

Table 1. Students' Perception on CBT in Final Examination

\begin{tabular}{|c|c|c|c|c|c|}
\hline No. & Tanggapan Siswa & $\mathbf{S}$ & ST & TS & STS \\
\hline 1. & $\begin{array}{l}\text { Siswa dapat mengetahui prosedur dalam mengerjakan soal } \\
\text { ujian berbasis komputer. Table }\end{array}$ & 23 & 6 & 1 & 0 \\
\hline 2. & $\begin{array}{l}\text { Mengetahui gambaran tentang pelaksanaan ujian nasional } \\
\text { berbasis computer. }\end{array}$ & 12 & 5 & 13 & 0 \\
\hline 3. & Icon-icon dalam program CBT sudah familiar. & 11 & 0 & 19 & 0 \\
\hline 4. & $\begin{array}{l}\text { Memahami pengoperasi program ujian berbasis computer } \\
\text { (CBT). }\end{array}$ & 24 & 0 & 6 & 0 \\
\hline 5. & $\begin{array}{l}\text { Sekolah mengadakan pelatihan untuk mengoperasikan CBT } \\
\text { dalam ujian nasional. }\end{array}$ & 7 & 23 & 0 & 0 \\
\hline 6. & $\begin{array}{l}\text { Siswa merasa nyaman dalam mengerjakan soal UN } \\
\text { menggunakan CBT. }\end{array}$ & 18 & 6 & 6 & 0 \\
\hline 7. & Pengawasan dalam pengerjaan ujian nasional sangat ketat. & 1 & 0 & 27 & 2 \\
\hline 8. & Ujian berlangsung dengan tertib dan lancar. & 24 & 6 & 0 & 0 \\
\hline 9. & Sarana dan prasarana CBT sudah memadai. & 18 & 12 & 0 & 0 \\
\hline 10. & $\begin{array}{l}\text { Saya merasa sudah cukup pembagian waktu yang } \\
\text { dibutuhkan untuk mengisi soal. }\end{array}$ & 23 & 7 & 0 & 0 \\
\hline 11. & $\begin{array}{l}\text { Guru yang mengawasi ujian sangat ramah dan memberikan } \\
\text { bantuan ketika ada siswa yang mengalami kendala ketika } \\
\text { mengoperasikan CBT saat ujian berlangsung. }\end{array}$ & 5 & 24 & 1 & 0 \\
\hline 12. & $\begin{array}{l}\text { Posisi penempatan tempat duduk sudah nyaman, tidak } \\
\text { terlalu merapat dengan teman-teman lainnya. }\end{array}$ & 19 & 11 & 0 & 0 \\
\hline 13. & $\begin{array}{l}\text { Suasana ujian tidak gaduh dengan suara teman-teman yang } \\
\text { biasa suka menanyakan tentang jawaban }\end{array}$ & 20 & 7 & 3 & 0 \\
\hline 14. & $\begin{array}{l}\text { Menggunakan CBT menghindari kecurangan dalam } \\
\text { mengerjakan ujian nasional. }\end{array}$ & 9 & 21 & 0 & 0 \\
\hline 15. & $\begin{array}{l}\text { Peserta ujian tidak repot seperti biasanya, tinggal menekan } \\
\text { (mengklik) pilihan jawaban saja yang sudah tersedia pada } \\
\text { layar computer. }\end{array}$ & 14 & 16 & 0 & 0 \\
\hline 16. & $\begin{array}{l}\text { Siswa dapat mengatur pembagian waktu untuk menjawab } \\
\text { soal ujian. }\end{array}$ & 22 & 8 & 0 & 0 \\
\hline
\end{tabular}




\begin{tabular}{|c|c|c|c|c|c|}
\hline 17. & $\begin{array}{l}\text { Pelaksanaan CBT dalam ujian lebih efektif dari PBT (Paper- } \\
\text { Based Test). }\end{array}$ & 13 & 17 & 0 & 0 \\
\hline 18. & Hasil ujian CBT lebih cepat dari hasil PBT. & 5 & 25 & 0 & 0 \\
\hline 19. & $\begin{array}{l}\text { Koneksi internet dalam mengerjakan ujian tidak ada } \\
\text { hambatan. }\end{array}$ & 24 & 2 & 4 & 0 \\
\hline 20 . & $\begin{array}{l}\text { CBT harus dipertahankan dalam Ujian Nasional } \\
\text { kedepannya, karena dinilai lebih efektif dari bentuk ujian } \\
\text { sebelumnya yakni PBT. }\end{array}$ & 0 & 30 & 0 & 0 \\
\hline
\end{tabular}

Based on these interview guide the researchers know that the students' perception who used Computer Based Test (CBT) are agreed in using Computer Based Test as their tool in the final examination.

\section{Discussion}

Based on the interview guide that answered by students, the researchers know that not only agree but also with this interview guide the researchers know that Computer Based Test (CBT) is effective for final examination to avoid the bad situation in the classroom while the students in the examination such as cheating with their friends in the final exam. These data also answer that 23 from 30 students know how to operate the system on their final examination used Computer Based Test (CBT). It means that almost of the students get the procedure before they used the computer and almost of the students' interest in final examination using Computer-Based Testing (CBT) with giving their attention in the procedure before the test. Not only operation but also in the situation of the final exam was fluent. It is based on the 24 students' perception that giving their perception if the situation in the final examination using CBT (Computer Based Testing) was going fluently and orderly until the examination is done. On the other hand, habitually in the final examination some of the students always asking the tasks during the examination. In contrast with the final examination that using CBT (Computer Based Test) the students could produce good situation without waste their times to asking the task or make noises in the classroom while they are doing the final examination. It is also based on the interview guide that shown 20 students agree on the 13 points.

Not to mention that based on the interview guide, 24 from 30 students give and agree on the perception that the process in the final examination with the CBT (Computer
Based Test) was going well as possible as the connection of the internet. It means that almost of the students are satisfied with the process of the CBT (Computer Based Test) that no worried about the internet connection during the final test.

Looking back on the interview guide that none of 30 students are disagree with perception that the CBT (Computer Based Test) must away or disappear from the one of tool or alternative in the final examination. From this point we can said that the CBT (Computer Based Test) is effective to make the final examination better from the previous final examination that not used.

\section{CONCLUSION AND SUGGEST}

Based on the data acquired from 30 students who used CBT (Computer Based Test) with their perception based on the interview guide that they got, the data in the interview guide shown that 1). Almost 30 students give their perception that CBT is an effective one for the students in the final examination. None of the students give the negative perception with disagreeing in using CBT although some of the students still difficult in using final examination with CBT (Computer Based Test). 2). Not only their perception but also the CBT could elimination the habitual in the final examination such as cheating with their friends. It is based on 22 students give their perception that they could not waste the time while they were in the process of CBT. It means that the CBT produces the good final examination with elimination of cheating cases in the national examinations using time in each question.

The results of this study are almost 30 students give their perception that the CBT is the effective one for the students in the final examination and the CBT produce the good final examination with the elimination of 
cheating cases in the National examinations using time in each question.

\section{REFERENCES}

All, A., Castellar, E. P. N., \& Van Looy, J. (2016). Assessing the effectiveness of digital game-based learning: Best practices. Computers \& Education, 92, 90103.

Baskarada, S. (2014). Qualitative case study guidelines. Baškarada, S.(2014). Qualitative case studies guidelines. The Qualitative Report, 19(40), 1-25.

Darmawan, D., \& Harahap, E. (2016). Communication strategy for enhancing quality of graduates nonformal education through computer based test $(\mathrm{CBT})$ in West Java Indonesia.

De Massis, A., \& Kotlar, J. (2014). The case study method in family business research: Guidelines for qualitative scholarship. Journal of Family Business Strategy, 5(1), 15-29.

Erle, L., Benjamin, O., Einar, W.S., \& Raymond, S. (2006). Computer-based versus Penand-paper Testing: Students' Perception. Ann Acad Med Singapore 35, 599-603.

Haddock-Millar, J., Sanyal, C., \& MüllerCamen, M. (2016). Green human resource management: a comparative qualitative case study of a United States multinational corporation. The International Journal of Human Resource Management, 27(2), 192-211.

Harrison, H., Birks, M., Franklin, R., \& Mills, J. (2017). Case study research: Foundations and methodological orientations. In Forum Qualitative Sozialforschung/Forum: Qualitative Social Research (Vol. 18, No. 1).

He, J., \& Freeman, L. A. (2019). Are men more technology-oriented than women? The role of gender on the development of general computer self-efficacy of college students. Journal of Information Systems Education, 21(2), 7.
Hillier, M. (2015). e-Exams with student owned devices: Student voices. In International Mobile Learning Festival Conference (pp. 582-608).

Houghton, C., Murphy, K., Shaw, D., \& Casey, D. (2015). Qualitative case study data analysis: An example from practice. Nurse researcher, 22(5).

Hyett, N., Kenny, A., \& Dickson-Swift, V. (2014). Methodology or method? A critical review of qualitative case study reports. International journal of qualitative studies on health and well-being, 9(1), 23606 .

Kaufman, A. S. (2018). Contemporary intellectual assessment: Theories, tests, and issues. Guilford Publications.

Kraushaar, J. M., \& Novak, D. C. (2019). Examining the affects of student multitasking with laptops during the lecture. Journal of Information Systems Education, 21(2), 11.

Marzuki, A. G. (2019a). The Implementation of SQ3R Method to Develop Students' Reading Skill on Islamic Texts in EFL Class in Indonesia. Register Journal, 12(1), 49-61.

Marzuki, A. G. (2019b). Utilizing Recorded English Dialogues in Teaching English Word Stress to Islamic Higher Education Students in Indonesia. Jurnal Pendidikan Islam, 5(1), 53-64.

Marzuki, A. G., Alim, N., \& Wekke, I. S. (2018). Improving the reading comprehension through cognitive reading strategies in language class of coastal area in indonesia. In IOP Conference Series: Earth and Environmental Science (Vol. 156, No. 1, p. 012050). IOP Publishing.

Marzuki, A.G. (2016). Utilizing cooperative learning in islamic college students' classroom, IJEE (Indonesian Journal of English Education), Vo. 3 No. 2, p. 123139.

Marzuki, A.G. (2017). Developing speaking skill through oral report in an efl class in indonesia, Al-Ta'lim Journal, Vo. 24 No. 3, p. 243-254. 
Mueller, S. T., \& Piper, B. J. (2014). The psychology experiment building language (PEBL) and PEBL test battery. Journal of neuroscience methods, 222, 250-259.

Parker, Robyn E. Bianchi, Alison and Cheah, Tsui Yi. (2008). Perceptions of InstructionalTechnology: Factors of Influence and Anticipated Consequences. Journal of Educational Technology \& Society. 11,2

Sorana-Daniela, B. \& Lorentz, J. (2007). Computer-based testing on physical chemistry topic: A case study. International Journal of Education and Development using Information and Communication Technology, 3(1), 94-95.

Su, C. H., \& Cheng, C. H. (2015). A mobile gamification learning system for improving the learning motivation and achievements. Journal of Computer Assisted Learning, 31(3), 268-286.
Witt, J. K. (2010). Perception: Performance and Ease Influence Perceived Speed. Journal of Experimental Psychology. 39.

Yazan, B. (2015). Three approaches to case study methods in education: Yin, Merriam, and Stake. The qualitative report, 20(2), 134-152.

Yovel, I., Mor, N., \& Shakarov, H. (2014). Examination of the core cognitive components of cognitive behavioral therapy and acceptance and commitment therapy: An analogue investigation. Behavior therapy, 45(4), 482-494.

Zygouris, S., \& Tsolaki, M. (2015). Computerized cognitive testing for older adults: a review. American Journal of Alzheimer's Disease \& Other Dementias ${ }^{\circledR}, 30(1), 13-28$. 